\title{
OPTIMIZATION OF INNOVATIVE STRIP-TILL TECHNOLOGY OF MAIZE CULTIVATION FOR GRAIN ON BLACK SOILS IN STEPPE ZONE OF VOLGOGRAD REGION
}

\author{
V.M. Ivanov, A.V. Kubareva \\ Volgograd State Agricultural University \\ Universitetskiy pr, 26, Volgograd, 400002, Russian Federation
}

\begin{abstract}
Studies carried out in steppe zone of chernozem soils of Volgograd region have established that winter wheat after fallow and maize are the best precursors for maize, cultivated for grain under strip-till technology. Growing maize after sunflower annually led to a significant decrease in crop yields. $\mathrm{N}_{66} \mathrm{P}_{32} \mathrm{~K}_{32}$ turned to be the best rate of mineral fertilizers. Seeding rate of 60 thousand seeds per ha was optimal for early maize hybrids. It was found that total water consumption over the three-year period was $2653 \mathrm{~m}^{3} / \mathrm{ha}$ with fertilizer rate $\mathrm{N}_{66} \mathrm{P}_{32} \mathrm{~K}_{32}$, and corn and sunflower rose to 2,700 and $2,695 \mathrm{~m}^{3} / \mathrm{ha}$. At $\mathrm{N}_{66} \mathrm{P}_{32} \mathrm{~K}_{32}$, winter wheat plants used moisture most economically. The water consumption coefficient, which shows moisture consumption for creation of a ton of produce, was $421.0 \mathrm{~m}^{3} / \mathrm{t}$. For corn, it increased by 34.1 , and for sunflower by $247.7 \mathrm{~m}^{3} / \mathrm{t}$. In control after all precursors, moisture consumption per ton of grain sharply increased: according to winter wheat, water consumption coefficient was equal to $551.9 \mathrm{~m}^{3} / \mathrm{t}$, corn and sunflower were 53.0 and $360.1 \mathrm{~m}^{3} / \mathrm{t}$ more. The maximum values of dry matter accumulation in 2013 and 2015 were recorded at flowering stage: depending on precursor, after winter wheat -9.07 and $7.24 \mathrm{t} / \mathrm{ha}$, after maize -8.67 and 6.77 , and after sunflower -6.64 and $4.76 \mathrm{t} / \mathrm{ha}$, respectively. Over the research years the largest daily increasing of dry biomass during germination-flowering was observed after winter wheat - 452 and $361 \mathrm{~kg} / \mathrm{ha}$, decreased slightly after corn - 432 and $337 \mathrm{~kg} / \mathrm{ha}$, and a significant decrease was noted after sunflower - 331 and $237 \mathrm{~kg} / \mathrm{ha}$. In arid 2014 season, during the period of precipitation deficit, the indicators were significantly lower. The best yield results were obtained in more favorable 2013 and 2015 research years. The studies showed that the best maize precursor was winter wheat $5.524 \mathrm{t} / \mathrm{ha}$. The lowest yield was obtained after sunflower - 3,456 t/ha. Moreover, maximum yield was achieved at fertilizer application $\mathrm{N}_{66} \mathrm{P}_{32} \mathrm{~K}_{32}-5.324 \mathrm{t} / \mathrm{ha}, \mathrm{N}_{50} \mathrm{P}_{16} \mathrm{~K}_{16}-4.813 \mathrm{t} / \mathrm{ha}$ and in the control $4.015 \mathrm{t} / \mathrm{ha}$.
\end{abstract}

Keywords: maize for grain, mineral fertilizers, seeding rate, precursor, strip-till, yield

\section{INTRODUCTION}

It is important to preserve and enhance natural fertility of soil based on development and introduction of new technologies. It is essential to achieve a sharp reduction in material and energy costs [1]. A promising method is the innovative strip-till system, which allows increasing grain production, increasing yield, saving fuel, since entire soil surface of field is not processed [2-4]. The peculiarity of strip-till technology is that soil is treated with strips, while in intermediate regions the soil remains unplowed, and natural structure remains intact as in direct sowing [5-7]. Strip-till technology also contributes to better warming of soil and better contact of seeds with it [8]. Intensive cultivation of maize for grain allows for higher yields 2.4 times under unfavorable conditions and 2.1 times - in good weather conditions in comparison with the control $[9,10]$. 


\section{MATERIALS AND METHODS}

The research was carried out on Krasnokorotkovsky experimental field in Novoanninskiy district of the Volgograd region in 2013 - 2015 to develop elements of the innovative strip-till technology. A three-factorial experiment was laid by the split plot method. Factor A was precursors - winter wheat after black fallow, maize for grain, sunflower; factor B - rates of mineral fertilizers - control (without fertilizers), $\mathrm{N}_{50} \mathrm{P}_{16} \mathrm{~K}_{16}\left(\mathrm{~N}_{16} \mathrm{P}_{16} \mathrm{~K}_{16}\right.$ - for the main application $+\mathrm{N}_{34}$ for fertilizing, $\mathrm{N}_{66} \mathrm{P}_{32} \mathrm{~K}_{32}$ $\left(\mathrm{N}_{32} \mathrm{P}_{32} \mathrm{~K}_{32}+\mathrm{N}_{34}\right.$ for fertilizing) and factor $\mathrm{C}$ - seeding rates: 50, 60 and 70 thousand of seeds per ha. The registration area of third-grade plot was $182 \mathrm{~m}^{2}$. The soil in the experiment is southern chernozem with a humus content of $4.7 \%, \mathrm{pH} 8$, total nitrogen $84.7 \mathrm{mg} / \mathrm{kg}$ (very low), mobile phosphorus - $43.4 \mathrm{mg} / \mathrm{kg}$ (increased), exchange potassium $395.0 \mathrm{mg} / \mathrm{kg}$ (increased). Early hybrid 'NK Gitago' (FAO 200) was used.

In autumn systemic herbicide Rap was used, 36\% water solution (A) at a dose of 4 1/ha with a working fluid consumption of $501 /$ ha. The strips were cut in October by Ortman cultivator with a depth of $23-25 \mathrm{~cm}$ and a width of $25 \mathrm{~cm}$ with simultaneous application of main fertilizer in liquid form. The sowing was carried out by 6-row Monosem seed drill to $6 . .7 \mathrm{~cm}$ depth. In 2013 sowing was carried out on April 22, in 2014 - May 5 and in 2015 — on May 26. Herbicide Ballerina, 41.7\% suspension emulsion was applied at $0.41 /$ ha with a working fluid consumption of $200 \mathrm{l} / \mathrm{ha}$ for crop protection in the phase of 3-5 leaves, and Vetter cultivator was used to carry out $\mathrm{N}_{34}$ ammonium nitrate fertilizing in variants $\mathrm{N}_{16} \mathrm{P}_{16} \mathrm{~K}_{16}$ и $\mathrm{N}_{32} \mathrm{P}_{32} \mathrm{~K}_{32}$. In 2014 pests population (stem moth, cotton scoop) reached Economic Threshold Limit (ETL), and therefore, Karate Zeon insecticide was used for their destruction, at a dose of $0.21 /$ ha. Harvesting was carried out by Akros-530 combine harvester with corn mower Orosh.

\section{RESULTS AND DISCUSSION}

The weather conditions were different. Amount of precipitation was $199 \mathrm{~mm}$ during sowing-full ripeness period in 2013, $127 \mathrm{~mm}$ in 2014 and $235 \mathrm{~mm}$ in 2015 . The average humidity was $30 \%$ in $2013,27 \%$ in 2014 and $31 \%$ in 2015 , and the average daily air temperature was $23.0{ }^{\circ} \mathrm{C}, 27.1{ }^{\circ} \mathrm{C}$ and $23.7{ }^{\circ} \mathrm{C}$, respectively. The hydrothermal coefficient was 0.75 in 2013 and this period was estimated as dry, in $2014-0.42$ (very arid), and in $2015-0.92$ (arid).

Field maize germination was high and averaged for 3 years $91.4 \%$ after winter wheat, $91.0 \%$ after maize and $89.9 \%$ after sunflower. Total survival reached $87.4 \%$, $85.3 \%$ and $83.5 \%$, respectively.

Maize vegetative period in 2013 and 2015 in fertilized variant $\mathrm{N}_{66} \mathrm{P}_{32} \mathrm{~K}_{32}$ after winter wheat and maize lasted 100 days, and after sunflower - 98 days. In the control, it decreased by one day according to experiment variants. In arid 2014 vegetative period was 2 days shorter: in the first fertilizer variant it was 98, 98, 96 days, and in the second - 97, 97 and 95 days.

The total water consumption over three-year period at $\mathrm{N}_{66} \mathrm{P}_{32} \mathrm{~K}_{32}$ fertilization after winter wheat was $2653 \mathrm{~m}^{3} / \mathrm{ha}$, after maize and sunflower it increased to 2700 and $2695 \mathrm{~m}^{3} /$ ha, respectively (Table 1 ). Moisture was used most economically at $\mathrm{N}_{66} \mathrm{P}_{32} \mathrm{~K}_{32}$ 
fertilization after winter wheat. The water consumption coefficient was $421.0 \mathrm{~m}^{3} / \mathrm{t}$. After maize and sunflower it increased by 34.1 and $247.7 \mathrm{~m}^{3} / \mathrm{t}$, respectively. In control variant after all precursors moisture consumption per ton of grain sharply increased: after winter wheat water consumption coefficient was $551.9 \mathrm{~m}^{3} / \mathrm{t}$, after maize and sunflower it was 53.0 and $360.1 \mathrm{~m}^{3} / \mathrm{t}$ more.

Table 1

\begin{abstract}
Total water consumption of maize for grain depending on precursor and fertilizer application at seeding rate 60 thousand of seeds per ha (average for 2013-2015), $\mathrm{mi} / \mathrm{ha}$
\end{abstract}

\begin{tabular}{|l|c|c|c|c|c|c|}
\hline \multirow{2}{*}{ Indicators } & \multicolumn{4}{|c|}{ Precursor } \\
\cline { 2 - 6 } & \multicolumn{2}{|c|}{ Winter wheat } & \multicolumn{2}{c|}{ Maize } & \multicolumn{2}{c|}{ Sunflower } \\
\cline { 2 - 6 } & untreated & $\mathrm{N}_{66} \mathrm{P}_{32} \mathrm{~K}_{32}$ & untreated & $\mathrm{N}_{66} \mathrm{P}_{32} \mathrm{~K}_{32}$ & untreated & $\mathrm{N}_{66} \mathrm{P}_{32} \mathrm{~K}_{32}$ \\
\hline $\begin{array}{l}\text { Available moisture } \\
\text { in 0-1,0 m (sowing), mi/ha }\end{array}$ & 1605 & 1604 & 1577 & 1577 & 1530 & 1529 \\
\hline $\begin{array}{l}\text { Precipitation during growing } \\
\text { season, mm }\end{array}$ & 187 & 187 & 187 & 187 & 187 & 187 \\
\hline $\begin{array}{l}\text { Precipitation used, } \\
\text { C=0.7, mm }\end{array}$ & 130.9 & 130.9 & 130.9 & 130.9 & 130.9 & 130.9 \\
\hline $\begin{array}{l}\text { Available moisture in 0-1,0 m } \\
\text { (before harvesting), mi/ha }\end{array}$ & 252 & 260 & 178 & 186 & 134 & 143 \\
\hline $\begin{array}{l}\text { Total water consumption, } \\
\text { mi/ha }\end{array}$ & 2662 & 2653 & 2708 & 2700 & 2705 & 2695 \\
\hline $\begin{array}{l}\text { Precipitation in total water } \\
\text { consumption, \% }\end{array}$ & 49.2 & 49.3 & 48.3 & 48.5 & 48.4 & 48.6 \\
\hline $\begin{array}{l}\text { Soil moisture in total water } \\
\text { consumption, \% }\end{array}$ & 50.8 & 50.7 & 51.7 & 51.5 & 51.6 & 51.4 \\
\hline $\begin{array}{l}\text { Average daily water } \\
\text { consumption, mi/ha }\end{array}$ & 26.9 & 26.7 & 27.6 & 27.2 & 28.1 & 27.7 \\
\hline Yield, t/ha & 4.823 & 6.302 & 4.477 & 5.933 & 2.966 & 4.030 \\
\hline $\begin{array}{l}\text { Coefficient of water } \\
\text { consumption, mi/t }\end{array}$ & 551.9 & 421.0 & 604.9 & 455.1 & 912.0 & 668.7 \\
\hline $\begin{array}{l}\text { The amount of grain per 1 mm } \\
\text { of productive moisture, } \mathrm{kg}\end{array}$ & 18.1 & 23.8 & 16.5 & 21.9 & 10.9 & 14.9 \\
\hline
\end{tabular}

The least amount of grain per mm of productive moisture $(10.9 \mathrm{~kg})$ was formed after sunflower at zero fertilizer application, and the largest $(23.8 \mathrm{~kg})$ - after winter wheat at $\mathrm{N}_{66} \mathrm{P}_{32} \mathrm{~K}_{32}$ fertilization.

Most leaves were formed during heading stage, and winter wheat, maize and sunflower leaf mass averaged 35.07, 33.81 and 27.20 thousand $\mathrm{m}^{2} /$ hectare. In terms of mineral nutrition, control was the least responsive, and amounted 29.30 thousand $\mathrm{m}^{2} / \mathrm{ha}$, at $\mathrm{N}_{50} \mathrm{P}_{16} \mathrm{~K}_{16}$ and $\mathrm{N}_{66} \mathrm{P}_{32} \mathrm{~K}_{32}$ this indicator reached 32.36 and 35.67 thousand $\mathrm{m}^{2} / \mathrm{ha}$. Increase in seeding rate resulted in increasing leaf area: for 50 thousand seeds/ha it was 30.74 thousand $\mathrm{m}^{2} /$ ha, for 60 thousand seeds/ha -31.89 and for 70 thousand seeds/ha -33.45 thousand $\mathrm{m}^{2} /$ ha.

Accumulation of dry matter in 2013 and 2015 had maximum values at flowering phase: after winter wheat -9.07 and $7.24 \mathrm{t} / \mathrm{ha}$, maize -8.67 and $6.77 \mathrm{t} / \mathrm{ha}$, and sunflower - 6.64 and $4.76 \mathrm{t} / \mathrm{ha}$. The greatest average daily increase in dry biomass during seedlings - flowering was observed after winter wheat - 452 and $361 \mathrm{~kg} / \mathrm{ha}$, it decreased slightly after maize — 432 and 337 t/ha, and a significant decrease was 
recorded after sunflower - 331 and $237 \mathrm{~kg} / \mathrm{ha}$ in 2013 and 2015, respectively. In dry 2014 these indicators were significantly lower. Accumulation of dry biomass was the best at $\mathrm{N}_{66} \mathrm{P}_{32} \mathrm{~K}_{32}$ fertilizing: in 2013 - 9.30 t/ha, in 2014 and 2015 - less by 3.55 and $2.54 \mathrm{t} / \mathrm{ha}$. Average daily growth for 2013, 2014 and 2015 was as follows: 463, 286 and $337 \mathrm{~kg} / \mathrm{ha}$, respectively. According to the factor C, on average, over the years of study, Accumulation of dry matter at seed rates 50,000, 60,000 and 70,000 seeds/ha was $6.37,6.60$ and $6.61 \mathrm{t} / \mathrm{ha}$. The average daily increase in the factor of seed rate was slightly lower at $50,000 \mathrm{seeds} / \mathrm{ha}-317 \mathrm{~kg} / \mathrm{ha}$, and at 60,000 and 70,000 seeds/ha $329 \mathrm{~kg} / \mathrm{ha}$. In full ripeness weight of maize dry matter after winter wheat reached 6.03 and $4.87 \mathrm{t} / \mathrm{ha}$, after maize -5.77 and $4.51 \mathrm{t} / \mathrm{ha}$, after sunflower -4.42 and $3.16 \mathrm{t} / \mathrm{ha}$. Accumulation of dry biomass in 2014 was 4.35 t/ha after winter wheat, and after maize and sunflower it decreased by 0.35 and $2.33 \mathrm{t} / \mathrm{ha}$.

Average daily growth of dry biomass for three-year data in flowering — full ripeness period after winter wheat was $319 \mathrm{~kg} / \mathrm{ha}$, after maize - $300 \mathrm{~kg} / \mathrm{ha}$ and after sunflower - $206 \mathrm{~kg} / \mathrm{ha}$. Application of mineral fertilizers contributed to an increase in dry matter accumulation. So, at $\mathrm{N}_{50} \mathrm{P}_{16} \mathrm{~K}_{16}$ for research years it was $4.46 \mathrm{t} / \mathrm{ha}$, at $\mathrm{N}_{66} \mathrm{P}_{32} \mathrm{~K}_{32}$ - $4.84 \mathrm{t} / \mathrm{ha}$, and at zero fertilizing — only $3.86 \mathrm{t} / \mathrm{ha}$ have accumulated. The average daily growth of dry biomass was: without fertilizer $-240 \mathrm{~kg} / \mathrm{ha}$, at $\mathrm{N}_{50} \mathrm{P}_{16} \mathrm{~K}_{16}-281 \mathrm{~kg} / \mathrm{ha}$, at $\mathrm{N}_{66} \mathrm{P}_{32} \mathrm{~K}_{32}-304 \mathrm{~kg} / \mathrm{ha}$. Accumulation of dry biomass at seed rate of 50, 60 and 70 thousand seeds/ha was $4.24,4.39$ and $4.42 \mathrm{t} / \mathrm{ha}$. The average daily plant biomass increase at seed rate of 50 thousand seeds/ha was $267 \mathrm{~kg} / \mathrm{ha}$, at 60 and 70 thousand seeds/ha it was $279 \mathrm{~kg} / \mathrm{ha}$.

Photosynthetic potential (PP) in 2013 and 2015 was maximum, it reached 2217 and 1883 thousand $\mathrm{m}^{2} \times$ day/ha after winter wheat, 2159 and $1765 \mathrm{~m}^{2} \times$ day/ha after maize, 1773 and 1400 thousand $\mathrm{m}^{2} \times$ day/ha after sunflower. PP in 2014 amounted to 1772,1658 and 1068 thousand $\mathrm{m}^{2} \times$ day/ha after winter wheat, maize and sunflower. Application of $\mathrm{N}_{50} \mathrm{P}_{16} \mathrm{~K}_{16}$ and $\mathrm{N}_{66} \mathrm{P}_{32} \mathrm{~K}_{32}$ increased PP for three-year data to 1764 and 1897 thousand $\mathrm{m}^{2} \times$ day/ha, and without fertilizing it reached 1583 thousand $\mathrm{m}^{2} \times$ day/ha. As seed rate increased, photosynthetic potential of crops increased: at 50, 60 and 70 thousand seeds/ha it amounted to 1681,1745 and 1818 thousand $\mathrm{m}^{2} \times$ day/ha.

In 2013, 2014, 2015 net photosynthetic rate (NP) for precursors studied was 6.39 , 6.35 and $5.53 \mathrm{~g} / \mathrm{m}^{2} /$ day, respectively. The best results were obtained in $\mathrm{N}_{66} \mathrm{P}_{32} \mathrm{~K}_{32}$ variant, when NP averaged $6.25 \mathrm{~g} / \mathrm{m}^{2} /$ day, while in $\mathrm{N}_{50} \mathrm{P}_{16} \mathrm{~K}_{16}$ and in control fertilizer variants it decreased by 0.06 and $0.42 \mathrm{~g} / \mathrm{m}^{2} /$ day, respectively. Optimal seed rates were 50 and 60 thousand seeds/ha, (6.19 and $6.16 \mathrm{~g} / \mathrm{m}^{2} /$ day $)$ and at 70 thousand seeds/ha NP was $5.92 \mathrm{~g} / \mathrm{m}^{2} /$ day.

On average over the research years, the largest mass of grain from commodity cobs was formed when corn was grown after winter wheat $-104.5 \mathrm{~g}$. After maize and sunflower it decreased to 100.0 and $68.9 \mathrm{~g}$. The weight of 1000 grains for these precursors was $255.6,248.3$ and $219.9 \mathrm{~g}$, respectively. Grain mass was the best at variant with $\mathrm{N}_{66} \mathrm{P}_{32} \mathrm{~K}_{32}, 50$ thousand seeds/ha seed rate (100.6 $\mathrm{g}$ and $101.3 \mathrm{~g}, 255.2$ and $252.4 \mathrm{~g}$, respectively).

Maize yield was influenced not only by meteorological conditions, but also by cultivation technology studied (Table 2). The best results were obtained in more favorable 
2013 and 2015 research years. Winter wheat turned to be the best maize precursor $5.524 \mathrm{t} / \mathrm{ha}$. The lowest yield was obtained after sunflower $-3.456 \mathrm{t} / \mathrm{ha}$. The maximum yield was achieved at $\mathrm{N}_{66} \mathrm{P}_{32} \mathrm{~K}_{32}$ fertilizer application $-5.324 \mathrm{t} /$ ha, and then $\mathrm{N}_{50} \mathrm{P}_{16} \mathrm{~K}_{16}$ (4.813 t/ha) compared to the control (4.015 t/ha). The optimal seed rate for average of 3 years was 60 thousand seeds/ha, and in unfavorable year 2014, the best was 50 thousand seeds/ha, which is confirmed by the statistical processing data.

Table 2

Corn grain yield depending on precursors,

fertilizer doses and seed rates in 2013-2015, t/ha

\begin{tabular}{|c|c|c|c|c|c|c|c|c|c|}
\hline \multirow{3}{*}{$\begin{array}{l}\text { Factors } \\
\text { and } \\
\text { combi- } \\
\text { nations }\end{array}$} & \multirow{2}{*}{\multicolumn{3}{|c|}{2013}} & \multirow{2}{*}{\multicolumn{3}{|c|}{2014}} & \multicolumn{3}{|c|}{2015} \\
\hline & & & & & & & \multicolumn{3}{|c|}{ average $2013-2015$} \\
\hline & $\begin{array}{l}\text { Winter } \\
\text { wheat }\end{array}$ & Maize & $\begin{array}{c}\text { Sun- } \\
\text { flower }\end{array}$ & $\begin{array}{l}\text { Winter } \\
\text { wheat }\end{array}$ & Maize & $\begin{array}{l}\text { Sun- } \\
\text { flower }\end{array}$ & $\begin{array}{l}\text { Winter } \\
\text { wheat }\end{array}$ & Maize & $\begin{array}{l}\text { Sun- } \\
\text { flower }\end{array}$ \\
\hline \multirow[t]{2}{*}{$A$} & \multirow[t]{2}{*}{6.615} & \multirow[t]{2}{*}{6.310} & \multirow[t]{2}{*}{4.790} & \multirow[t]{2}{*}{4.695} & \multirow[t]{2}{*}{4.293} & \multirow[t]{2}{*}{2.142} & 5.263 & 4.926 & 3.421 \\
\hline & & & & & & & 5.524 & 5.176 & 3.451 \\
\hline \multirow[t]{6}{*}{$\mathrm{B}$} & \multirow{6}{*}{\multicolumn{3}{|c|}{$\begin{array}{c}\text { control }-4.842 \\
\text { N50P16K16 - 6.039 } \\
\text { N66P32K32-6.835 }\end{array}$}} & \multirow{6}{*}{\multicolumn{3}{|c|}{$\begin{array}{c}\text { control }-3.190 \\
\text { N50P16K16 -3.785 } \\
\text { N66P32K32 -4.154 }\end{array}$}} & \multirow{2}{*}{\multicolumn{2}{|c|}{ control }} & 4.012 \\
\hline & & & & & & & & & 4.024 \\
\hline & & & & & & & \multirow{2}{*}{\multicolumn{2}{|c|}{ N50P16K16 }} & 4.614 \\
\hline & & & & & & & & & 4.813 \\
\hline & & & & & & & \multirow{2}{*}{\multicolumn{2}{|c|}{ N66P32K32 }} & 4.984 \\
\hline & & & & & & & & & 5.324 \\
\hline \multirow[t]{6}{*}{$\mathrm{C}$} & \multirow{6}{*}{\multicolumn{3}{|c|}{$\begin{array}{l}50 \text { thousand }-5.570 \\
60 \text { thousand }-6.081 \\
70 \text { thousand }-6.065\end{array}$}} & \multirow{6}{*}{\multicolumn{3}{|c|}{$\begin{array}{l}50 \text { thousand }-3.814 \\
60 \text { thousand }-3.734 \\
70 \text { thousand }-3.581\end{array}$}} & \multirow{2}{*}{\multicolumn{2}{|c|}{50 thousand }} & 4.488 \\
\hline & & & & & & & & & 4.624 \\
\hline & & & & & & & \multirow{2}{*}{\multicolumn{2}{|c|}{60 thousand }} & 4.615 \\
\hline & & & & & & & & & 4.810 \\
\hline & & & & & & & \multirow{2}{*}{\multicolumn{2}{|c|}{70 thousand }} & 4.506 \\
\hline & & & & & & & & & 4.717 \\
\hline
\end{tabular}

$\mathrm{LSD}_{05}$ 2013: A,B,C $=0.064, \mathrm{AB}, \mathrm{AC}, \mathrm{BC}=0.110, \mathrm{ABC}=0.064$

$\mathrm{LSD}_{05}$ 2014: A,B,C $=0.061, \mathrm{AB}, \mathrm{AC}, \mathrm{BC}=0.106, \mathrm{ABC}=0.061$

$\mathrm{LSD}_{05}$ 2015: A,B,C $=0.066, \mathrm{AB}, \mathrm{AC}, \mathrm{BC}=0.114, \mathrm{ABC}=0.066$

\section{CONCLUSIONS}

The experiments showed that the best maize precursors were winter wheat after black fallow and maize in cultivation of maize for grain using strip-till technology in steppe zone on chernozem soils in Volgograd region,. Sunflower was the worst maize precursor.

The best mineral nutrition was $\mathrm{N}_{66} \mathrm{P}_{32} \mathrm{~K}_{32}$.

Optimal seed rate for early maize hybrid was 60 thousand seeds/ha.

(C) V.M. Ivanov, A.V. Kubareva, 2018.

\section{REFERENCES}

[1] Petrov NY, Imangaliev KN, Davydov SV, Zenina EA. Resource-saving technology of maize cultivation for grain in Volgograd Region. Agrarnyj vestnik Urala. 2008; 52(10):52 - 53. (In Russ).

[2] Meinel T. Strip-till: Innovation Kazakhstan agriculture. Pole deyatel'nosti. 2013;(11):55-57. (In Russ). 
[3] Dudenhoeffer CJ, Nelson KA, Motavalli PP, Burdick B, Dunn D, Goyne KW. Utility of phosphorus enhancers and strip-tillage for corn production. Journal of Agricultural Science. 2013;5(2):37-46.

[4] Paudel B, Radovich TJ, Chan-Halbrendt C, Crow S, Tamang BB, Halbrendt J, Thapa K. Effect of conservation agriculture on maize-based farming system in the mid-hills of Nepal. Procedia Engineering. 2014;78:327-336.

[5] Belyaev VI, Meinel T, Tiessen RU. Strip-till technology: design and application features of the equipment of leading global manufacturers. Bulletin of ASAU. 2013;109(11):86 -91. (In Russ).

[6] Borisenko IB, Sokolova MV. Strip-till technology as a response to tasks of a modern farmer. Poisk innovatsionnykh putei razvitiya zemledeliya $v$ sovremennykh usloviyakh: Materialy mezhdunarodnoi nauchno-prakticheskoi konferentsii posvyashchennoi 70-letiyu Volgogradskogo gosudarstvennogo agrarnogo universiteta i kafedry «Zemledelie i agrokhimiya»; 2014 may 14; Volgograd. Volgograd: Volgogradskii GAU Publ.; 2014. p.114-117. (In Russ).

[7] Kravchenko RV, Troneva OV. Effect of basic tillage on the efficiency of maize cultivation in Stavropol territory. Scientific Journal of KubSAU. 2011;71(7):680 - 689. (In Russ).

[8] DeJong-Hughes J, Vetsch J. On-farm comparison of conservation tillage systems for corn following soybeans. University of Minnesota Extension; 2007.

[9] Domanov NM, Ibadullaev KB, Gorokhova ZY. Agroecological efficiency of maize cultivation technologies depending on degree of intensity and weather conditions. Vestnik of VSAU. 2011;29(2):30-33. (In Russ).

[10] Fedorenko VP, Pashchenko YM, Dudka EL. Corn protection under intensive cultivation technology. Zashchita i karantin rastenii. 2011;(5): 17-24. (In Russ).

\title{
Author's personal data:
}

Vladimir Mihajlovich Ivanov — Doctor of Agricultural Science, professor, Volgograd State Agricultural University; e-mail: ivanov-vgsxa@mail.ru

Anastasia Vladimirovna Kubareva — PhD student, Volgograd State Agricultural University; e-mail: ivanov-vgsxa@mail.ru,

\section{For citation:}

Ivanov V.M., Kubareva A.V. Optimization of innovative strip-till technology of maize cultivation for grain on chernozem soils in steppe zone of Volgograd region. Journal of Agronomy and Animal Industries, 2018, 13 (3), 224—231. doi: 10.22363/2312-797X-2018-13-3-224-231.

\section{ОПТИМИЗАЦИЯ ЭЛЕМЕНТОВ ИННОВАЦИОННОЙ ТЕХНОЛОГИИ СТРИП-ТИЛ ПРИ ВОЗДЕЛЫВАНИИ КУКУРУЗЫ НА ЗЕРНО В СТЕПНОЙ ЗОНЕ ЧЕРНОЗЕМНЫХ ПОЧВ ВОЛГОГРАДСКОЙ ОБЛАСТИ}

\author{
В.М. Иванов, А.В. Кубарева
}

ФГБОУ ВО Волгоградский государственный аграрный университет пр. Университетский, 26, Волгоград, 400002, Российская Федераџия

Проведенными исследованиями в степной зоне черноземных почв Волгоградской области установлено, что для кукурузы, возделываемой на зерно по технологии Стрип-тил, лучшими предшественниками являются озимая пшеница по пару и сама кукуруза. Размещение кукурузы 
после подсолнечника ежегодно обусловливало значительное снижение урожайности культуры. Из испытанных доз минеральных удобрений лучшей была $\mathrm{N}_{66} \mathrm{P}_{32} \mathrm{~K}_{32}$. Оптимальной для раннеспелых гибридов кукурузы являлась норма высева 60 тыс./га всхожих семян. Было установлено, что суммарное водопотребление за трехлетний период составило $2653 \mathrm{~m}^{3} /$ га с нормой удобрения $\mathrm{N}_{66} \mathrm{P}_{32} \mathrm{~K}_{32}$, а кукуруза и подсолнечник - до 2700 и $2695 \mathrm{M}^{3} /$ га. С дозой удобрений $\mathrm{N}_{66} \mathrm{P}_{32} \mathrm{~K}_{32}$, растения озимой пшеницы использовали влагу наиболее экономично. Коэффициент водопотребления, который показывает потребление влаги для создания тонны продукции, составил $421,0 \mathrm{~m}^{3} /$ т. Для кукурузы он увеличился на 34,1 , а для подсолнечника - на 247,7 м $^{3}$ т, соответственно. На контроле после всех предшественников потребление влаги на тонну зерна резко увеличилось: по озимой пшенице коэффициент водопотребления составлял 551,9 м³/т, кукуруза и подсолнечник - 53,0 и 360,1 м $3 /$. Максимальные значения накопления сухого вещества в 2013 и 2015 гг. выявлены на стадии цветения: в зависимости от предшественника, после озимой пшеницы — 9,07 и 7,24 т/га, после кукурузы 8,67 и 6,77 , а после подсолнечника - 6,64 и 4,76 т/га, соответственно. За годы исследований наибольшее ежедневное увеличение сухой биомассы во время прорастания-цветения наблюдалось после озимой пшеницы — 452 и 361 кг/га, несколько уменьшилось после кукурузы - 432 и 337 кг/га, а после подсолнечника отмечено значительное снижение - 331 и 237 кг/га. В засушливый сезон 2014 года, в период дефицита осадков, показатели были значительно ниже. Наилучшие результаты урожайности были получены в более благоприятные по увлажнению годы исследований в 2013 и 2015 гг. Исследования показали, что лучшим предшественником кукурузы была озимая пшеница — 5,524 т/га. Самый низкий урожай был получен после подсолнечника — 3,456 т/га. Кроме того, максимальный выход был достигнут при применении удобрений $\mathrm{N}_{66} \mathrm{P}_{32} \mathrm{~K}_{32}-5,244$ т/га, $\mathrm{N}_{50} \mathrm{P}_{16} \mathrm{~K}_{16}-4,813$ т/га, а на контроле - 4,015 т/га.

Ключевые слова: кукуруза на зерно, минеральные удобрения, норма высева, предшественник, Стрип-тил, урожайность

\section{БИБЛИОГРАФИЧЕСКИЙ СПИСОК}

[1] Петров Н.Ю. Ресурсосберегающая технология возделывания кукурузы на зерно в условиях Волгоградской области / Н.Ю. Петров, К.Н. Имангалиев, С.В. Давыдов, Е.А. Зенина // Аграрный вестник Урала. 2008. № 10 (52). С. 32-53.

[2] Майнель T. Strip-till: Инновация в земледелии Казахстана // Поле деятельности. 2013. № 11 . C. 55-57.

[3] Christopher, J Dudenhoeffer. Utility of Phosphorus Enhancers and Strip-Tillage for Corn Production / J. Christopher Dudenhoeffer, Kelly A. Nelson // Journal of Agricultural Sciences. 2013. No 2. pp. 37-46.

[4] Paudela Bikash. Effect of conservation agriculture on maize-based farming system in the midhills of Nepal / Bikash Paudela, Theodore J.K. Radovich, Catherine Chan-Halbrendta and other // Humanitarian Technology: Science, Systems and Global Impact. 2014. No 78. pp. 327-336.

[5] Беляев В.И. Технология Strip-till: особенности конструкций машин ведущих мировых производителей и их применение / В.И. Беляев, Т. Майнель, Р. Тиссен // Вестник Алтайского ГАУ. Научный журнал. 2013. № 11 (109). С. 86.

[6] Борисенко И.Б. Технология Strip-till как ответ на решение задач современного фермера / И.Б. Борисенко, М.В. Соколова // Поиск инновационных путей развития земледелия в современных условиях: Материалы междунар. научно-практ. конф. посвященной 70-летию Волг. гос. агр. ун-та и каф «Земледелие и агрохимия»: 14 мая 2014 г. г. Волгоград. Волгоград: ФГБОУ ВПО Волг. ГАУ, 2014. 532. С. 114-117.

[7] Кравченко P.В. Влияние основной обработки почвы на эффективность возделывания кукурузы в условиях Ставропольского края / Р.В. Кравченко, О.А. Тронева // Научный журнал КубГАУ. 2011. № 71 (07). С. 613-622.

[8] DeJong-Hughes Jodi. On-Farm Comparison of Conservation Tillage Systems for Corn Following Soybeans / Jodi DeJong-Hughes, Jeffrey Vetsch // University of Minnesota Extension. 2007. BU-08483. 
[9] Доманов Н.М. Агроэкологическая эффективность технологий возделывания кукурузы на зерно в зависимости от степени интенсивности и погодных условий / Н.М. Доманов, К.Б. Ибадуллаев и др. // Вестник Воронежского ГАУ. 2011. № 2 (29). С. 30 -33.

[10] Федоренко В.П. Защита кукурузы при интенсивной технологии ее возделывания // Защита и карантин растений. 2011. № 5. С. 17-24. Catherine Chan-Halbrendta and other // Humanitarian Technology: Science, Systems and Global Impact. 2014. No 78. pp. 327-336.

\section{Для цитирования:}

Иванов В.М., Кубарева А.В. Оптимизация элементов инновационной технологии Стрип-тил при возделывании кукурузы на зерно в степной зоне черноземных почв Волгоградской области // Вестник Российского университета дружбы народов. Серия: Агрономия и животноводство. 2018. Т. 13. № 3. С. 224-231. doi: 10.22363/2312-797X-2018-13-3-224-231. 